\title{
Development and Policy: Rethinking Hegemonic Concepts and Ideas
}

\author{
Vera Schattan P. Coelho
}

\begin{abstract}
1 Introduction
The IDS40 Roundtable in Brazil recognised economic growth, cash transfer programmes such as 'Bolsa Familia', and equity in access to welfare policies, as the main mechanisms to promote development and reduce poverty and social inequality. However, at the IDS40 conference, I could not help but be surprised by the challenging proposal put forward by Wolfgang Sachs that we should rethink the question of equity not in terms of growing consumption, but rather through an effort to reduce it. One of the reactions to Sachs' intriguing suggestion came from an Indian colleague who drew attention to the practical difficulties of realising such a proposal. After all, he argued, how could politicians and governments stand up in front of their constituencies and be re-elected for promising to reduce consumption? The findings of the Brazil Roundtable and this comment at the conference are testimony to the enduring force of the idea of development as a project of growth and equity that can be achieved through nation states. But Sachs' proposal also highlights the fact that new ideas about 'what development should be' are gaining space in this age-old debate.
\end{abstract}

In this brief reflection, I will argue that this debate deserves attention for two reasons. The first and most trivial is that it deals with the permanent need to negotiate politically 'what development should be'. The second is concerned with the representativeness of the political process through which the very meaning and goals of development are negotiated. The changing nature of development today has brought sub-national and global actors onto the scene. On many occasions they are unable to be adequately represented through national political systems and traditional forms of representation.
These transformations force us to reflect more carefully on the capacity of the traditional representative institutions - both national and international - to guarantee the necessary political space for a reformulation of development and what it should be. Below, I briefly present some of the analytical problems associated with this question that were discussed in the conference. Finally, I review this discussion from the perspective of contemporary democratic theory.

\section{Development and its protagonists}

The time has long since past when capitalists and subordinated classes were the principal protagonists of development; when the state was seen as the driving force; when development was understood as a synonym for the industrialisation process at a national level. The Roundtable process and national debates in so many countries highlighted the diversity of perspectives on these issues (see Haddad's overview article, this IDS Bulletin). This diversity reiterated the great uncertainty that now exists regarding the meaning of development, as well as the limits and relative potential of the economy, science, politics or the state - or even how national and global institutions can stimulate processes of development.

\section{During the conference there was a clear tension} between those who understand the state as the privileged locus for the coordination of development projects and those who, although recognising its importance, support views that emphasise the active role of society in this process. In addition, there are distinct visions between those who consider civil society as a whole and those who see fundamental cleavages within society, and passionately defend changes 'from below' as the only way to promote transformations in 
the status quo. And there are others who are drawing attention to the new actors connected with the management of global governance. Those actors could be decisive in confronting threats to development such as: epidemics and pandemics, hunger and food insecurity and violence. Finally, there are some who suspect that these various different actors and arrangements are powerless in the face of major and influential transnational corporations, which may be the only bodies that truly have the power to determine the viability of different development projects.

This was the ongoing analytical scenario that prevailed in the conference. There were persistent doubts about the meaning of development and enquiries into the role of different actors, a debate that convinced me that it is vital for us to carefully re-examine the political processes that are opening up space for a renegotiation and reformulation about what development should be. The following section is an attempt to relate this discussion within the framework of contemporary democratic theory.

\section{New forms of representation?}

Debates about political participation have grown noticeably over recent decades (Gaventa 2006). The idea that political participation is carried out only through voting or protesting changed, above all, after Habermas' work on deliberative democracy (Habermas 1989; Cohen and Arato 1992); also as a result of the theory of empowered deliberative democracy inspired by participatory experiences such as participatory budgeting in Porto Alegre and participatory planning in Kerala (Fung and Wright 2003) and, additionally, by the opening of spaces allowing the increased involvement of users in the management of public policies (UNDP 2002). From the point of view of the discussion here it is useful to ask to what extent these different forms of political participation might be combined into a political framework capable of promoting a meaningful

\section{References}

Cohen, J. and Arato A. (1992) Civil Society and Political Theory, Cambridge, MA: MIT Press

Cornwall, A. and Coelho V. (2006) Spaces for Change? The Politics of Participation in New Democratic Arenas, London: Zed Books

Fung, A. and Wright E. (2003) Deepening Democracy: Institutional Innovation in Empowered Participatory Governance, London: Verso

Gaventa, J. (2006) 'Deepening the Deepening engagement by both central actors as well as less organised groups involved in processes of development.

Whereas voting gives citizens of a particular country the chance of periodically choosing their representatives, each of the other analytical models look at a different locus of political involvement. Deliberative democracy is concentrated mainly in the public sphere and seeks to strengthen the power of civil society vis-a-vis the state and the market. This is based on the assumption that this will be possible because citizens, who are bearers of rights and liberties, will come together to formulate a common public project and put pressure on the state to recognise it. Empowered deliberative democracy focuses on the state sphere and takes a neo-corporative approach in order to guarantee a place in the political process for the underprivileged citizens, aiming to enlarge their power in relation not only to the bureaucracy and the market, but also in face of privileged segments of civil society. Finally, perspectives about the involvement of users in the management of public policies seek to empower civil society in face of state bureaucracy and corrupt elites.

This broad picture shows that contemporary debates surrounding the notion of 'democratic innovation' have encompassed a range of normative models and experiences (Cornwall and Coelho 2006). In this context, one of the challenges that face those who are concerned with rethinking research about development is to investigate how global actors as well as networks from below, working with various forms of political involvement described above (voting, mobilisation and different forms of participation), can re-elaborate the notion of development. Also, how it can expand it beyond that of the national political system, to enable a more open and inclusive discussion to redefine 'what development should be'.

Democracy Debate', foreword to A. Cornwall and V. Coelho, Spaces for Change? The Politics of Participation in New Democratic Arenas, London: Zed Books

Habermas, J. (1989) The Structural Transformation of the Public Sphere, Cambridge, MA: MIT Press

UNDP (2002) Human Development Report 2002: Deepening Democracy in a Fragmented World, New York: United Nations Development Programme 